17. Фоменко, Н. В. Рекреаційні ресурси та курортологія. Навчальний посібник [Текст] / Н. В. Фоменко. - К. : Центр навчальної літератури, 2007. - 312 c.

18. Цьохла, С. Ю. Трансформація рекреаційної діяльності та розвиток регіональних ринків курортнорекреаційних послуг (методологія, аналіз і шляхи вдосконалення): монографія [Текст] / С. Ю. Цьохла. Сімферополь : Таврія, 2012. - 352 с.

19. Черванев, И. Г. Математические методы в географии [Текст] / И. Г. Черванев, А. П. Голиков, А. М. Трофимов. - Харьков. : ХГУ,1986. - 348 с.

20. Шищенко, П. Прикладна фізична географія [Текст] / П. Г. Шищенко. - К. : Либідь, 2003. - 343 с.

UDC 338.483(477.54)

*S. I. Reshetchenko, PhD (Geography), Associate Professor,

*N. I. Cherkashyna, Senior Lecturer,

**O. V. Babaieva, PhD (Geography), Associate Professor,

*V. N. Karazin Kharkiv National University,

** Institute of Trade and Economics

\title{
PHYSICAL AND GEOGRAPHICAL PRINCIPLES OF TOURIST CLUSTER'S FORMATION IN KHARKIV REGION
}

С. І. Решетченко, Н. І. Черкашина, О. В. Бабаєва. ФІЗИКО-ГЕОГРАФІЧНІ ЗАСАДИ ФОРМУВАННЯ ТУРИСТИЧНОГО КЛАСТЕРУ ХАРКІВСЬКОЇ ОБЛАСТІ. У статті розглядаються основні фізико-географічні фактори (кліматичні, водні, лісові, рельєф) формування туристичного кластеру на території Харківської області. Кластерний підхід дає змогу визначити пріоритетні напрямки розвитку туристичної діяльності, максимально використовувати природні умови та проводити природоохоронні заходи. Сьогодні туристичний кластер виступає як інновачійна форма розвитку регіональної економіки, отже туризм є одним із факторів соціально-економічного функиіонування території. Туристично-рекреаційна діяльність також відіграє головну роль у міжнародно-економічних зв 'язках. Формування туристичного кластеру території дозволить ефективно використовувати всі доступні туристично-рекреаційні ресурси регіону. Дослідження кліматичних показників проводилося за допомогою статистичного методу, де аналізувалися часові ряди середньомісячних значень температури повітря, атмосферних опадів, сонячної радіації за період 2001-2015 рр. За методикою Н.В. Фоменко встановлено, що територія Харківської області для рекреаиії та туристичної діяльності за показниками «клімат», «лісові ресурси», «рельєф» характеризується оцінкою «добре». В той же час за показником «водні ресурси» досліджувана територія має задовільну оцінку. В иілому на території області наявні всі фізико-географічні фактори для подальшого перспективного розвитку туристичного кластеру.

Ключові слова: туристичний кластер, фізико-географічні фактори, туристичний ринок, кліматичні ресурси, рекреаційні ресурси, водні ресурси, рельєф, Харківська область.

С. И. Решетченко, Н. И. Черкашина, Е. В. Бабаева. ФИЗИКО-ГЕОГРАФИЧЕСКИЕ АСПЕКТЫ ФОРМИРОВАНИЯ ТУРИСТИЧЕСКОГО КЛАСТЕРА ХАРЬКОВСКОЙ ОБЛАСТИ. В статье рассматриваются основные физикогеографические факторы (климатические, водные, лесные, рельеф) формирования туристического кластера на территории Харьковской области. Кластерный подход позволяет определить приоритетные направления развития туристической деятельности, максимально использовать природнье условия и проводить природоохраняемье мероприятия. Сегодня туристический кластер рассматривают как инновачионную форму развития региональной экономики, поскольку туризм является одним из факторов социально-экономического функиионирования территории. Туристическо-рекреационная деятельность также имеет главное значение в международно-экономических связях. Формирование туристического кластера территории позволит эффективно использовать все доступные туристическо-рекреационные ресурсы территории. Исследование климатических показателей проводилось с помощью статистического метода, где анализировались временные ряды среднемесячных значений температуры воздуха, атмосферных осадков, солнечной радиации за период 2001-2015 года. По методике Н.В. Фоменко было определено, что территория Харьковской области для рекреации и туристической деятельности по показателям «климат», «лесные ресурсы»" «рельеф» характеризуется оченкой «хорошо». В то же время по показателю «водные ресурсы» исследуемая территория имеет удовлетворительную оценку. В изелом на территории области наличествуют все физико-географические факторы для дальнейшего перспективного развития туристического класmера.

Ключевые слова: туристический кластер, туристический рынок, климатические ресурсы, рекреационные ресурсы, водные ресурсы, рельеф, физико-географические факторы. Харьковская область.

Formulation of the problem. In recent years, the cluster approach has become a key tool of tourism policy in the leading European countries. However, our country still has little experience in creating tourist clusters, since it is a relatively new direction in tourism development. In addition, Ukraine has insufficiently developed legal and informational support for creation and operation of tourist clusters.

To assess the potential of tourist cluster development in Kharkiv region it is necessary to analyze a number of factors, such as natural-geographical, historical-cultural and socio-economic ones, which determine the creation of a regional tourist market.

Analysis of recent research and publications. Many works by foreign and Ukrainian scholars, including A. Trebukh [12], S. Sokolenko [9], M. Porter [6], M. Rutinsky, T. Tkachenko [11], I. Dyshlovoi [4], M. Slipenchuk and others, are devoted to the theories and methodologies of tourist clusters. A tourist cluster is understood as a set of economic 
entities' activities offering services in the field of tourism.There are small and large firms in their composition that interact with each other and are concentrated on the territory, interacting in the production and marketing of the tourist product.

Several features of tourist clusters classification have been adopted in modern scientific literature: according to the territorial criterion (M. Porter, S. Nordin, A. Alexandrova, D. Stechko, etc.) [6, 10], by types of tourism (T.I. Tkachenko) [11] and by industry specifics (O.O. Bunakov) [2].

Selection of previously unsettled parts of the general problem. Despite a considerable number of scientific publications, definining "tourist cluster", the factors of the tourism market clusterization of Kharkiv oblast are not fully determined and generalized. At the same time, each region has its own peculiarities of tourism development, and its recreational resources play an important role in this issue.

Setting objectives. The purpose of this article is to study the natural-geographical criteria for the formation of the tourist cluster in Kharkiv region, their evaluation and generalization.

\section{Presentation of main material.}

Given the fact that Kharkiv region is in the northeast of Ukraine, it is characterized by a peripheral location. In general, its area is approaching a circle, determining equivalent relations between the regional center and the outskirts. The peculiarity of the location is that it borders directly on the developed industrial-economic regions of the country, namely, Dnipropetrovsk, Donetsk, Luhansk regions.

The relief of Kharkiv region is mostly undulating, it is a plain, cut by river valleys, valley floors and power ravines. The peculiarities of the terrain in the region are emphasized by burial mounds (graves) created by man in ancient times, which increases historical and cultural value of the region under study. They line up mainly on natural highlands and are dispersed throughout the region, more commonly found in the south of the studied region.

The relief, along with other physical and geographical factors, affects recreational activities and, consequently, recreational and tourist industry in a particular region [13]. By N.V. Fomenko [14], recreational resources of the territory can be estimated on factors such as climate, forest vegetation, reservoirs and relief. According to his methodology of recreational area assessment, prevailing relief of Kharkiv region corresponds to the indicator "good" - stepby-step, erosion-divided and generally contributes to the development of the tourist-recrational industry (Table 1).

Weather conditions in Kharkiv region are favorable for recreational and tourist activities [13]. They correspond to the indicators of optimal climatic conditions for recreation (Table 2).
The territory, located at moderate latitudes, receives sufficient amounts of solar radiation: sunlight duration in winter is 8 hours, in summer - 16-17 hours. Total duration of sunshine is gradually increasing from March (116 hours) to June (290 hours), furtheron it decreases. In total, it is over 1900 hours per year. The temperature regime of the territory is determined by annual radiation balance, positive in summer and negative in winter.

Instability of air temperature in winter is due to a significant change in circulatory factors in the Atlantic-European region [3]. In summer, the temperature regime of the territory is determined by radiation factors. The hottest months of the year are July and August with average monthly temperature of $22.7^{\circ} \mathrm{C}$ and $21.5^{\circ} \mathrm{C}$, respectively. The southeastern part of the region is distinguished by high air temperatures and low rainfall [7-8].

In the warm period of the year, the surface of the region is a green array of forests, fields, meadows. The amount of solar radiation is sufficient. Evaporation increases in conditions of cloudless weather, contributing to the development of convective clouds, forming stormy short rains. Forests are preserved in the river valleys: on steep slopes, upland terraces and the Siversky Donets catch. Forest arrays soften temperature indices relative to the open area, reduce wind speed and have greater air humidity.

Thus, on the territory of Kharkiv region winter is moderate and cold, while the summer is moderate and hot. In general, the eastern part is colder than the western one. In the north-western areas there are fewer dry wind days.

Humidity affects weather conditions of the territory, determining its recreational and tourist use. Rainfall distribution per months and territories is uneven in the studied region: in the cold season there is less precipitation, with rain and snow predominating. In the warm period of the year precipitation is more intense but less prolonged.

Modern wind conditions are characterized by decrease in wind speed: winter period with a maximum in February is characterized by the highest speed. In summer, there is a significant decrease in speed with minimum is June. Eastern winds have greatest repetition in the cold period of the year (December, January, February, March). Western and northwestern winds prevail in summer,south-eastern ones prevail in spring.

Analysis of wind directions repetition indicates the warm and winter seasons. Winds of a western component dominate in the warm season, while in winter they blow eastward.

Hence, climatic resources of Kharkiv region are favorable for recreation, especially for summer types, such as beach, sports, cognitive recreation. 
Territory assessment for stationary recreation [14].

Climate, vegetation, reservoirs, relief are gradually assessed

\begin{tabular}{|c|c|c|c|c|}
\hline Indices & $\begin{array}{l}\text { Climate (favourable climat- } \\
\text { ic conditions during:) }\end{array}$ & Forest vegetation & $\begin{array}{l}\text { Water reser- } \\
\text { voirs }\end{array}$ & Relief \\
\hline$\stackrel{\varpi}{\varpi}$ & $\begin{array}{l}\text { 10-11 months : } \\
\text { - - warm summers and mod- } \\
\text { erately cold winters with a } \\
\text { stable snow cover; } \\
\text { - hot long summer and short } \\
\text { warm winter without a stable } \\
\text { snow cover }\end{array}$ & $\begin{array}{l}\text { dry pine, broadleaf, co- } \\
\text { niferous-deciduous for- } \\
\text { ests, mixed with admix- } \\
\text { ture of subtropical spe- } \\
\text { cies }\end{array}$ & $\begin{array}{l}\text { warm seas } \\
\text { with tempera- } \\
\text { ture of }>17^{\circ} \mathrm{C} \\
\text { for } \\
3-4 \text { months }\end{array}$ & $\begin{array}{l}\text { mountainous (up } \\
\text { to } 2 \mathrm{~km} \text { ), foothill } \\
\text { ordinary: divided }\end{array}$ \\
\hline $\begin{array}{l}3 \\
8 \\
0\end{array}$ & $\begin{array}{l}\text { 7-9 months: } \\
\text { hot and dry summers and } \\
\text { mild winters with stable } \\
\text { snow cover }\end{array}$ & $\begin{array}{l}\text { dry dark coniferous, de- } \\
\text { ciduous, cedar, small- } \\
\text { leaved forests }\end{array}$ & $\begin{array}{l}\text { warm lakes } \\
\text { and large riv- } \\
\text { ers, cool seas } \\
\text { with tempera- } \\
\text { ture } 16^{\circ} \mathrm{C} \text { for } \\
2-3 \text { months }\end{array}$ & $\begin{array}{l}\text { step-by-step, ero- } \\
\text { sion-divided }\end{array}$ \\
\hline 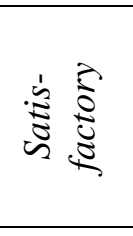 & $\begin{array}{l}\text { 3-6 months: } \\
\text { cool rainy summer and mild } \\
\text { winters with unstable snow } \\
\text { cover or hot dry summers } \\
\text { and harsh winters. }\end{array}$ & $\begin{array}{l}\text { partially marshy dark } \\
\text { conifers, deciduous and } \\
\text { mixed forests }\end{array}$ & $\begin{array}{l}\text { cool lakes, } \\
\text { water reser- } \\
\text { voirs, rivers } \\
\text { and cold seas }\end{array}$ & $\begin{array}{l}\text { Hilly, weakly di- } \\
\text { vided }\end{array}$ \\
\hline $\mathbb{Z}$ & $\begin{array}{l}\text { 2- } 3 \text { months: } \\
\text { hot dry summers and unsta- } \\
\text { ble winter with little snow } \\
\text { cover or without it. }\end{array}$ & $\begin{array}{l}\text { Near-tundra woodland, } \\
\text { deciduous forests in } \\
\text { combination with bogs }\end{array}$ & $\begin{array}{l}\text { warm small } \\
\text { and large cool } \\
\text { water reser- } \\
\text { voirs }\end{array}$ & flat-hilly \\
\hline$\frac{\sqrt{2}}{3}$ & $\begin{array}{l}\text { 1-2 months: } \\
\text { short cool summers and long } \\
\text { winter or hot summers and } \\
\text { snowless winters }\end{array}$ & $\begin{array}{l}\text { marsh forests, forest } \\
\text { tundra, forests in } \\
\text { swamps and small forest } \\
\text { areas among agricultural } \\
\text { lands }\end{array}$ & $\begin{array}{l}\text { cold water res- } \\
\text { ervoirs and } \\
\text { cold small riv- } \\
\text { ers with tem- } \\
\text { peratures } \\
<12^{\circ} \mathrm{C} \text {. }\end{array}$ & $\begin{array}{l}\text { flat or mountain- } \\
\text { ous (inaccessible } \\
\text { terrains) }\end{array}$ \\
\hline
\end{tabular}

Table 2

Parameters of optimum climatic conditions for recreation [14]

\begin{tabular}{|l|c|c|}
\hline \multicolumn{1}{|c|}{ Indices } & Summer period & Winter period \\
\hline Average daily air temperature, ${ }^{\circ} \mathrm{C}$ & $15-26$ & $-10 \ldots-25$ \\
\hline Wind speed, m/s & Up to 5 & Up to 5 \\
\hline Heliotherapy, days & $105-120$ & - \\
\hline Duration of beach-bathing period, days & $60-90$ & - \\
\hline Snow cover thickess , cm & - & $10-40$ \\
\hline Duration of the period for winter sports, days & - & $45-60$ \\
\hline
\end{tabular}

According to N. Fomenko's methodology of estimating the recreational territory (Table 1), the climatic resources of the studied region correspond to the indicator "good", as well as to the parameters of optimal climatic conditions for recreational purposes (Table 2).

Water resources of Kharkiv region are represented by rivers, lakes, swamps, ponds, reservoirs, canals, water conduits, underground waters. All watercourses and water objects of the region belong to the basins of the Don and the Dnieper rivers, covering respectively $3 / 4$ and $1 / 4$ of its territory, and are objects of national importance. The river network is unevenly distributed across the territory. The main river of the region is Siversky Donets with tributaries of the Oskil, Udy, Mzha. In Kharkiv region there are 57 reservoirs and 2538 ponds. Among them there are large reservoirs: Pecheniz'ke on the river Siversky Donets, Chervonooksilske on the Oskil River, Chervonopavlivske on the Dnipro-Donbas Canal. 
Kharkiv region is weakly and unevenly supplied with groundwater resources [1]. However, there are conditions for recreation development, especially in the coastal zones of such watercourses and reservoirs as the Siversky Donets, the Oskil river, and the Pecheniz'ke and Chervonozkilske reservoirs built on them. The region ranks fifth in Ukraine (after Chernihiv, Kyiv, Poltava and Kherson) in total groundwater reserves. Here, there are sufficient reserves of underground waters with lowmineralized hydrocarbon calcium composition, sodium chloride of various mineralization with healing properties and are used for therapeutic purposes. Resort and health-improving territories occupy 12,000 hectares. Kharkiv region is one of the main centers of balneotherapy on the left bank of Ukraine. The richest mineral water reserves are Berezivsky mineral waters and Rai-Olenivka [13]. These water resources correspond to the indicator "satisfactory" according to [14] (see Table 1).

The territory of Kharkiv region is located in two landscape zones - the forest-steppe (northern part of the region) and the steppe (southern part). Today steppe vegetation has almost disappeared, which is explained by excessive agricultural activity. The steppes have been plowed, with the exception of small protected areas of natural parks. Forests occupy 318 thousand hectares on the territory of the region. More than 1000 species and forms of trees and shrubs grow in the forests and parks of Kharkiv region.

The most widespread forest species are pedunculate oak and Scots pine. Spruce is also often found, as well as linden, maple, ash. Significant areas of broadleaf forests have survived on elevated sections of the right bank of the Siversky Donets and its tributaries Udy, Lopan, Kharkiv, and others. Forest resources according to N.Fomenko [14] (see Table 1) correspond to the indicator "good".

Conclusions. Thus, the main factors determining the organization of tourist and recreational activity on the territory of Kharkiv region are relief, climate, water and vegetation resources [13]. The region under study has sufficient recreational and tourist resources and good potential for their development, primarily of cognitive, river recreational, green and ecological tourism.

\section{References}

1. Бабаєва, О. В. Екологічні проблеми Харківської області на фоні глобального потепління / О. Бабаєва, С. Решетченко // Формування сучасного економічного простору : переваги, ризики, механізми реалізації : Мат. конферениії. - Тбілісі : Riga:Baltija Publishing. - 2016. - C. $188-191$.

2. Бунаков, О. А. Кластерный подход к позиционированию в туризме // Управление экономическими системами: электронный научный журнал, 2011. - № 4 (28). - [Електронний ресурс]. - Режим доступу : http://uecs.mcnip.ru.

3. Гончарова, Л. Д. Клімат і загальна циркулячія атмосфери / Л. Гончарова. - К. : КНТ, 2005. - 351c.

4. Дишловий, I. М. Питання формування та функціонування кластерів у рекреаційно-туристичному комплексі регіону / Дишловий I. М. // Економічні інновації. - 2011. - Вип. 44. - C. 79-89.

5. Климатологические стандартные нормы (1961 - 1990 г2.). - К., 2002. - 446 c.

6. Портер, М. Е. Международная конкуренция: Конкурентные преимущества стран / М. Е. Портер. - М. : Международные отношения, 1993. - 105 с.

7. Решетченко, С. І. Зміни середньомісячної температури повітря та опадів за період 1951-2010 рр. у Харкові / С. Решетченко, О. Бабаєва // Проблеми безперервної географічної освіти і картографії: зб. наук. праць. Харків : ХНУ імені В.Н. Каразіна, 2013. - Вип. 18. - С. 142-145.

8. Решетченко, С. І. Особливості динаміки атмосферних явищ на територї Харківської області / C. Решетченко, М. Христосов // Проблеми безперервної географічної освіти і картографії : зб. наук. праць. - Харків : ХНУ імені В. Н. Каразіна, 2017. - Вип. 26. - С. 61-66.

9. Соколенко, С. І. Розвиток економіки регіонів на основі інноваційних кластерів / С. I. Соколенко // Інвестиційно-інноваційний розвиток економіки регіону : Мат. IV з'їду Спілки екон. Украӥни. - К. : Навчальна книга - Богдан, 2010. - С. 100-106.

10. Стеченко, Д. М. Наукова сутність процесу кластеризації в сфері туризму / Д.М. Стеченко // Вісник Хмельницького інституту регіонального управління та права. - 2004. - № 1-2. - C.376-380.

11. Ткаченко, Т. I. Сталий розвиток туризму: теорія, методологія, реалї бізнесу: монографія / Т. I. Ткаченко. 2-ге вид., випр. та доповн. - К. : КНТЕУ, 2009. - 463 с.

12. Требух, А. А. Туристичний кластер як форма посилення конкурентних переваг регіону / А. Требух, Н. Бандура // Науковий вісник НДТУ України. - 2010. - С. 265-270.

13. Туристичний кластер Харківщчини. Монографія / Колектив авторів, заг.ред. О. Яковчук. -Харків : РВВ ХТЕI KHTEУ, 2017. - $400 \mathrm{c}$.

14. Фоменко, Н. В. Рекреаційні ресурси та курортологія / Н. Фоменко. - К. : Центр навчальної літератури, 2007. $-312 c$. 